\title{
Correction to: Shining light on deep-sea bioluminescence. Editorial comment on the highlight article "Biochemical characterization of diverse deep-sea anthozoan bioluminescence systems" by M. Bessho-Uehara et al. 2020
}

\author{
Christian R. Voolstra ${ }^{1}$
}

Published online: 26 July 2020

(C) The Author(s) 2020

\section{Correction to: Marine Biology (2020) 167:113 \\ https://doi.org/10.1007/s00227-020-03732-8}

Unfortunately, the author name in the article title is incorrectly published in the original online published article.

The correct article title should read as "Shining light on deep-sea bioluminescence. Editorial comment on the highlight article "Biochemical characterization of diverse deepsea anthozoan bioluminescence systems" by M. BesshoUehara et al. 2020"

The original article has been corrected.
Open Access This article is licensed under a Creative Commons Attribution 4.0 International License, which permits use, sharing, adaptation, distribution and reproduction in any medium or format, as long as you give appropriate credit to the original author(s) and the source, provide a link to the Creative Commons licence, and indicate if changes were made. The images or other third party material in this article are included in the article's Creative Commons licence, unless indicated otherwise in a credit line to the material. If material is not included in the article's Creative Commons licence and your intended use is not permitted by statutory regulation or exceeds the permitted use, you will need to obtain permission directly from the copyright holder. To view a copy of this licence, visit http://creativecommons.org/licenses/by/4.0/.

Publisher's Note Springer Nature remains neutral with regard to jurisdictional claims in published maps and institutional affiliations.

The original article can be found online at https://doi.org/10.1007/ s00227-020-03732-8.

Christian R. Voolstra

christian.voolstra@uni-konstanz.de

1 Department of Biology, University of Konstanz, Konstanz, Germany 